\title{
Healthcare values and potential uses of the new Hungarian apple varieties on the basis on fruit analysis
}

\author{
Ficzek, G. Ladányi, M. Radeczky, Zs. \& Tóth, M. \\ Department of Pomology, Faculty of Horticultural Science, Budapest Corvinus University \\ H-1118 Budapest, Villányi út 29-43.E-mail: gitta.ficzek@uni-corvinus.hu
}

\begin{abstract}
Summary: Biological active compounds and valuable characteristics of some apple varieties and candidates were measured in our trials. Fruits of 'Rosmerta', 'Hesztia', 'Cordelia' and 'Artemisz' are recommended to enrich the Hungarian assortments for fresh consumption and choice of new tastes. Based on examined parameters it can be assumed that novel Hungarian resistant varieties are suitable for juice and fruit concentrate production, and due to high pectin content of their remaining pomace these varieties can be raw material of pectin production as well as they are also suitable for jam production mixed with other fruit species. Furthermore, functional food industrial product having high quality can be produced by using novel resistant varieties because of their high pectin and polyphenol content. Beside of their high market value their suitability for growing among orchard conditions is confirmed by lower costs of production because of less plant protection treatments.
\end{abstract}

Key words: Apple (Malus $\times$ domestica Borkh.), apple breeding, resistance, physical parameters, nutritional value

\section{Introduction}

So-called civilian diseases mean more serious problems on the basis of speeded up lifestyle of today and unhealthy nutrition. The medical sciences show a keen interest in phytho-nutriens because this science prefers disease prevention instead of therapy. The results of the international research confirm beneficial effects of fruit species on human health (Wolfe et al., 2003).

Fruits of apple can be eaten in unlimited quantity for people who suffer from different illness (for instance obesity, diabetes, intestinal problems). Apple species have curative effects which can be utilized in the common therapy. Beside of fresh consumption apple fruit are suitable for producing products having functional effects (Oliveira et al., 2003; Lee and Chan, 2011).

Ecological conditions of Carpathian basin are excellent for growing apple which is confirmed by growing traditions. Apple species can be grown safety, were grown among Hungarian climate conditions, have special aroma and excellent fruit quality. Thanks to these reasons apple is grown in the largest volume of Hungary $(K S H, 2011,2012)$.

Fresh consumption of fruit species having significant biological activity as well as breeding for industrial purposes becomes ones of the most important aims in the future. Creation of new Hungarian apple assortment's means breeding of novel resistant and tolerant apple varieties coming out from breeding workshop of Department of Pomology of Corvinus University of Budapest (Tóth, 2005).

Aim of our research is to compare the new Hungarian multiresistant apple varieties, candidates, and commercial standard varieties by their healthcare compounds as well as their eating quality and their food industrial value. On one hand, we would like to add more information to purposeful breeding work on the basis of our research's results. On the other hand, we would like to popular health-conscious diet with some basic information. My null hypothesis is to decide whether apple varieties could be the important keystones in health-conscious diet of Hungarian society.

\section{Materials and methods}

\section{Examined varieties}

Apple samples were collected from Research and Experimental Farm of Department of Pomology of Corvinus University of Budapest (hereafter orchard in Soroksár). Fruits of the new resistant and tolerant apple candidates (MT-01, MT-11, MT-12, B-403) as well as novel Hungarian bred multiresistant ('Artemisz', 'Cordelia', 'Hesztia', 'Rosmerta') and commercial varieties ('Gala', 'Watson Jonathan', 'Idared') were examined in our trials. Apple fruit samples were picked by hand at the optimal ripening time from 4 trees of each variety (between 2007 and 2011).

\section{Methods of fruit analysis}

Physical parameters (weight, size parameters, flesh firmness) and inner content value (total soluble solid (Brix\%) and total acid content) of involved apple varieties were determined at the optimal picking time (between 
2007 and 2011) under laboratory conditions. Determination of total soluble solids was fulfilled based on CODEX ALIMENTARIUS 3-1-558/93 formula using ATAGO PR101 type digital refractometer. Total titratable acidity was determined with $0,1 \mathrm{n} \mathrm{NaOH}$ solution based on MSZ EN Nr 12147:1998 Hungarian Standard.

Antioxidant parameters, ferric reducing/antioxidant power (FRAP) and polyphenol concentrations were measured in the case of apple varieties as well (between 2009 and 2011). The (FRAP) assay was carried out according to Benzie and Strain (1996). The FRAP assay is based on the reduction of the Fe3+-2,4,6-tripyridyl-S-triazine complex to the ferrous form $(\mathrm{Fe} 2+)$ and the intensity of the reaction is monitored by measuring the change of absorption at $593 \mathrm{~nm}$. Polyphenol concentrations was measured on $=765 \mathrm{~nm}$ in the presence of Folin-Ciocaltens reagent. For this measurement gallic acid calibration curve was used according to the method of Singleton and Rossi (1965). The pectin content was determined with using Kyriakidis and Psoma (2001) method. After excavation in vitriol absorbance of samples were measured on $525 \mathrm{~nm}$ using Hitachi U.2800 spectrophotometer.

\section{Statistical evaluation method}

Statistical analyses of data were full fielded by PASW Statistic 18 program. To compare apple varieties hierarchic cluster analysis was used on the basis of examined years' data.

\section{Results and discussion}

\section{Valuable characteristics of apple varieties}

Today there are some foreign resistant apple varieties, which are available for growers however these varieties don't have big ratio in practice apart from some exceptions (e.g. 'Florina', 'Prima'). On one hand, reason of this can be explained by lack of marketing. On the other hand, reason also can be that early ripening resistant varieties introduced first in the production had poor fruit quality. Hungarian apple growing having varieties with excellent fruit quality should be competitive on home and international markets both fresh consumption and food industrial purposes. Comparison of novel bred resistant varieties as well as selected hybrids and well-known, wide-spread varieties in the Hungarian apple production was reasonable because of above mentioned fact. (2007-2011)
We can state that fruit weight (139 to $269 \mathrm{~g}$ ) of examined apple varieties vary on a very large scale, from the small size (MT-01, 'Rosmerta') to the very large size ('Cordelia') all size categories can be found (Table 1.). Except apple chips production processing industry doesn't have any demand on fruit size but fruits belong to different size categories are suitable for different consumer sections' demand.

There are basically different demands on varieties are suitable for fresh consumption and industrial processing. Apple's consumer preference is determined by harmonious taste depend on sugar/acid ratio principally (Harker et al., 2002). On the industrial processing's (concentrate, juice, puree, dried fruits) point of view other factors (susceptible to breakdown, acid, pectin and polyphenol content) play an important role (Nótin et al 2011). Resistant varieties (13.38 to $14.12 \mathrm{Brix} \%$ ) and candidates (13.15 to $14.62 \mathrm{Brix} \%$ ) have higher refraction value compared to 'Idared's and 'Gala's as well as 'Rosmerta' nears 'Watson Jonathan's refraction value. Acid content of examined varieties varied on a large scale ( 0.31 to $0.94 \%)$. Acid content of MT-01 and 'Gala' was similar to each other, both had low acid content but resistant 'Hesztia' and 'Rosmerta' neared, 'Artemisz' and 'Cordelia' exceeded acid content of 'Watson Jonathan', which is suitable for juice making.

Apple's flesh firmness has an important role because of food industrial point of view so varieties with firmer fruit flesh can be mostly pressed better. Demands on industry are firm tissue (Stégerné, 2007) but flesh texture has effects on consumption characteristic value and storage life as well. There were big differences in flesh firmness of examined apple varieties, all had enough firmness. 'Artemisz' (7.9 kg/ $\left.\mathrm{cm}^{2}\right)$ and 'Cordelia' $\left(8.28 \mathrm{~kg} / \mathrm{cm}^{2}\right)$ had extreme high flesh firmness but low flesh firmness of 'Rosmerta's fruits give possibility to produce different food industrial products (e.g. concentrate, puree).

Table 1. High, diameter, mass, firmness, refraction and total acid values of apple varieties in 5 years average

\begin{tabular}{|c|c|c|c|c|c|c|c|c|}
\hline Varieties & $\begin{array}{l}\text { High } \\
(\mathrm{mm})\end{array}$ & $\begin{array}{l}\text { Diameter } \\
(\mathrm{mm})\end{array}$ & $\begin{array}{l}\text { Fruit } \\
\text { weight } \\
\text { (g) }\end{array}$ & $\begin{array}{c}\text { Fruit } \\
\text { firmness } \\
\text { on sunny } \\
\text { side } \\
\left(\mathrm{kg} \cdot \mathrm{cm}^{-2}\right)\end{array}$ & $\begin{array}{c}\text { Fruit } \\
\text { firm- } \\
\text { ness on } \\
\text { shadow } \\
\text { side } \\
\left({\left.\mathrm{kg} . \mathrm{cm}^{-2}\right)}\right.\end{array}$ & $\begin{array}{c}\text { Fruit } \\
\text { firmness } \\
\text { average } \\
\left(\mathrm{kg} \cdot \mathrm{cm}^{-2}\right)\end{array}$ & $\begin{array}{c}\text { Total } \\
\text { soluble } \\
\text { solids } \\
\text { (Brix\%) }\end{array}$ & $\begin{array}{c}\text { Total } \\
\text { titratable } \\
\text { acidity } \\
(\%)\end{array}$ \\
\hline MT-01 & 58.21 & 69.86 & 138.78 & 6.61 & 7.38 & 6.99 & 14.62 & 0.48 \\
\hline MT-11 & 65.83 & 68.03 & 145.18 & 6.87 & 7.50 & 7.18 & 13.15 & 0.31 \\
\hline MT-12 & 68.66 & 74.77 & 182.79 & 6.92 & 7.53 & 7.23 & 13.33 & 0.44 \\
\hline B-403 & 68.14 & 72.89 & 170.41 & 6.74 & 7.29 & 7.02 & 13.79 & 0.34 \\
\hline Gala & 61.15 & 67.25 & 143.61 & 7.15 & 7.32 & 7.24 & 12.57 & 0.47 \\
\hline Artemisz & 58.01 & 72.14 & 147.01 & 7.85 & 8.31 & 7.95 & 13.94 & 0.94 \\
\hline Cordelia & 77.96 & 83.58 & 269.19 & 7.91 & 8.66 & 8.28 & 13.89 & 0.73 \\
\hline Hesztia & 73.61 & 84.02 & 245.43 & 6.53 & 6.85 & 6.69 & 13.38 & 0.69 \\
\hline Rosmerta & 59.42 & 73.38 & 154.37 & 5.78 & 6.32 & 6.05 & 14.12 & 0.69 \\
\hline $\begin{array}{l}\text { Watson } \\
\text { Jonathan }\end{array}$ & 61.44 & 71.73 & 149.41 & 6.47 & 6.98 & 6.72 & 14.34 & 0.72 \\
\hline Idared & 70.51 & 82.40 & 230.72 & 5.41 & 5.67 & 5.54 & 12.89 & 0.63 \\
\hline
\end{tabular}




\section{Health care value of apple varieties}

Pectin content of apple varieties influences not only on fruit flesh consistency and storage life but this compound means its most important healthcare value (Nara et al., 2001, Billy et al., 2008). 'Gala', 'Watson Jonathan', MT-01 and MT11 had low pectin content (Figure 1.). Fruits of 'Artemisz', 'Hesztia' and 'Rosmerta' contained similar pectin content like 'Idared' $(0.76 \%)$. 'Cordelia' fruits $(0.86 \%)$ had extremely high pectin, which was similar high like its flesh firmness. However resistant apple varieties had similar pectin content like 'Idared' but their values were higher compared to pectin content of 'Watson Jonathan' and 'Gala'. 'Cordelia', B-403 and MT-11 can have an important role in healthcare nutrition because of their outstanding pectin content.

Beside of high pectin content apple has a beneficial effect on human body thanks to its polyphenol content. Our polyphenol results show the figure 2. These results (194 to $479 \mathrm{mg} \mathrm{GS} / \mathrm{l}$ ) were nearly similar to results ( 99 to $451 \mathrm{mg} \mathrm{GS} / \mathrm{l}$ ) of hybrids and commercial varieties derived from Canadian breeding program (Khanizadeh at al., 2008). Sanoner and his research group (1999) measured higher and extraordinary unbalanced values in cider hybrids' and varieties' fruits (110 to 600 mg GS/l), which were from France breeding program. Furthermore, Petkovsek and his colleagues (2007) also had similar results (215 to 652 $\mathrm{mg} \mathrm{GS} / \mathrm{l}$ ) to Sanoner and his research group's (1999) results, they examined pectin content of scab resistant and susceptible varieties' fruits. On the basis of our results the lowest value was $107 \mathrm{mg} \mathrm{GS} / \mathrm{L}$ (on 'Gala') while the highest value was $392 \mathrm{mg} \mathrm{GS} / \mathrm{l}$ (on 'Hesztia') in average of three years. Difference was 3,6 times.

FRAP value showed similar differences compared to polyphenol value (Figure 3.). The lowest FRAP value was produced by 'Gala' $(0,47$ mmol AS/l), MT-01 had the highest one (1.44 mmol AS/l). Antioxidant capacity of both varieties showed more than treble differences. All examined samples derived from Research and Experimental Farm of Soroksár so fruit site conditions were same therefore it can be considered (2009-2011) that genetical background of variety determines its antioxidant characteristics basically. There are some research on studying relationship between resistance determined by genes and quantity of antioxidant compounds (Treutter, 2005, Petkovsek et al., 2007). According to Usenik and her research group's results (2004) polyphenol concentration of apple fruits determines degree of its resistance to Venturia inaequalis. Total flavanols content of scab resistant apple varieties was three times higher than susceptible varieties' by Treutter and Feucht's results (1990).

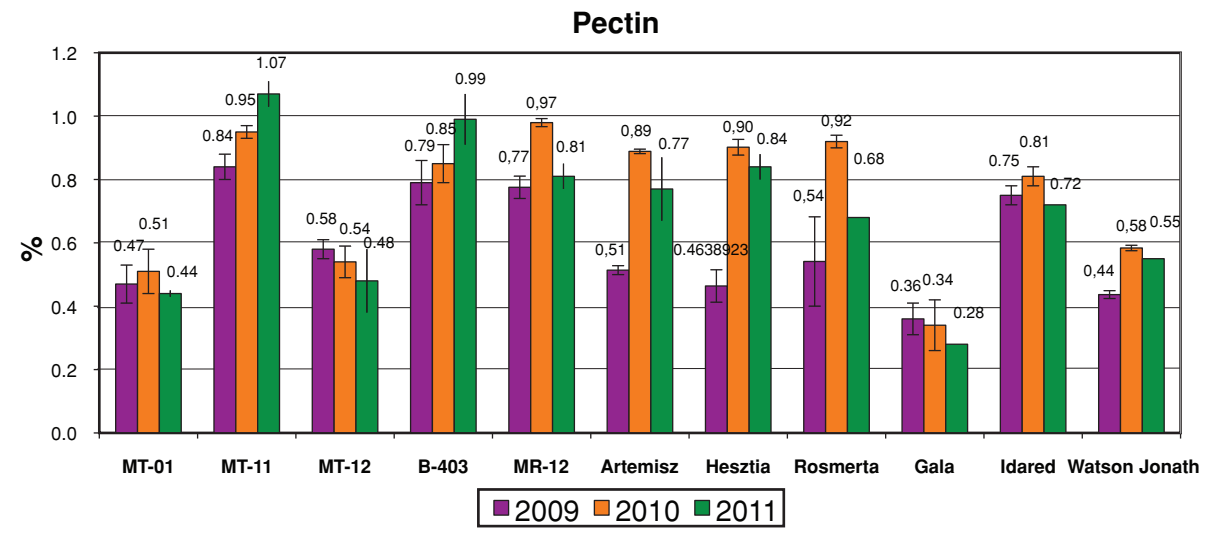

Figure 1. Pectin content of the fruits in eight new and three control varieties (2009-2011)

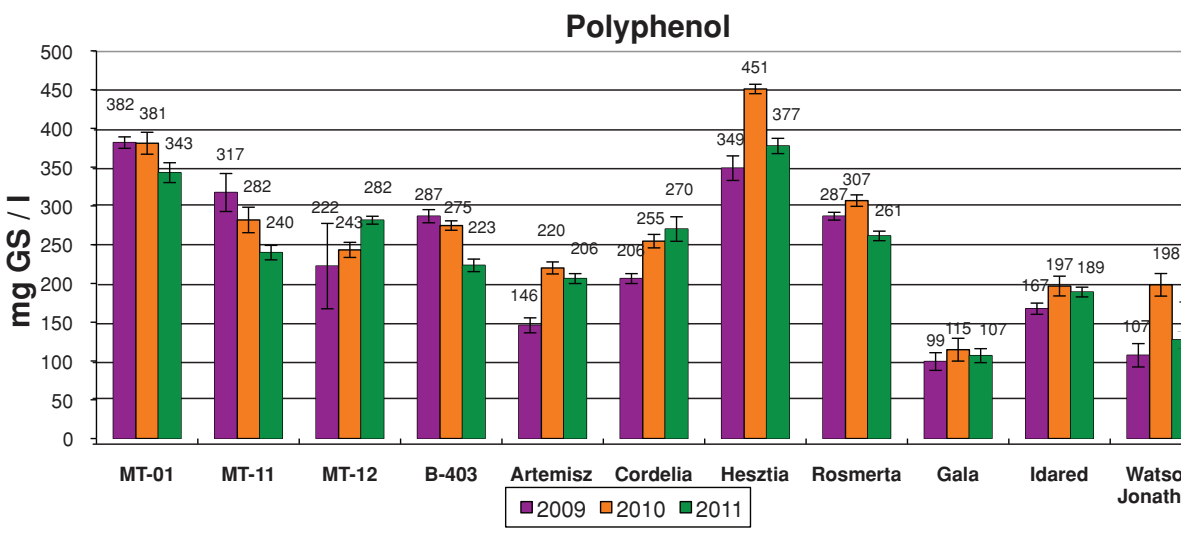

Figure 2. Polyphenol content of the fruits in eight new and three control varieties (2009-2011)

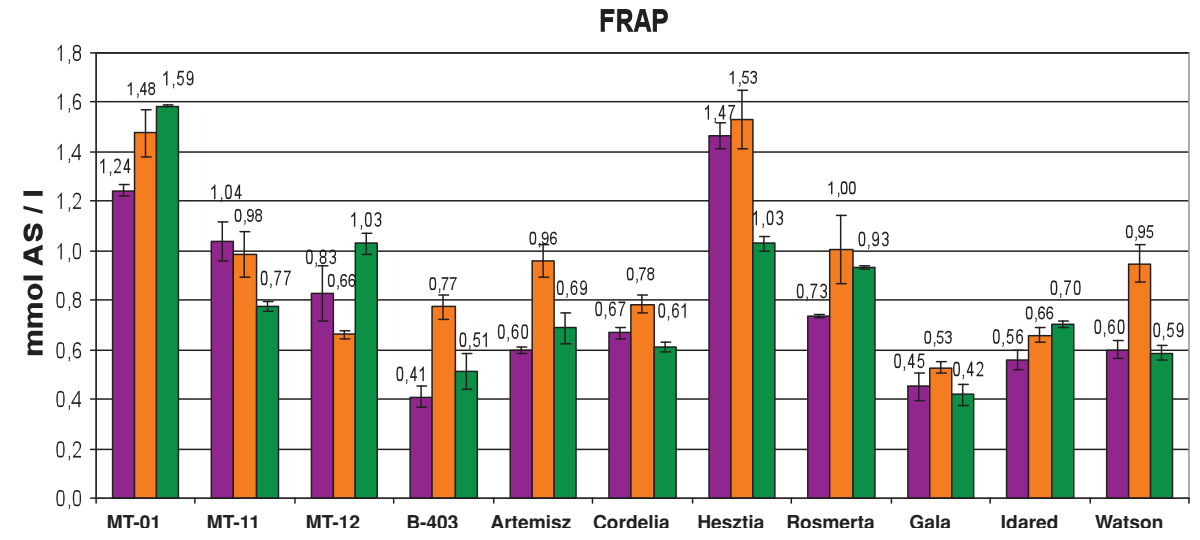

Figure 3. Water soluble antioxidant capacity (FRAP) of the fruits in eight new and three control varieties 
It can be stated that resistant varieties have higher polyphenol content compared to commercial varieties and their FRAP values near as well as in the case of some resistant varieties exceed significantly the sensitive varieties. 'Hesztia' and MT-01 can play an important role in healthcare nutrition in the future due to their antioxidants. Among the resistant varieties 'Artemisz' had the lowest polyphenol content and FRAP value, both were similar to commercial cultivars. Because of low polyphenol content and FRAP value 'Artemisz' is suitable for dried fruit production due to having less taste for breakdown.

\section{Conclusion}

We declare that the inner content value of all multiresistant apple varieties is near or exceed to commercial varieties. Importance of apples in healthcare can be thanked to its high pectin and polyphenol content. Pectin and polyphenol content of resistant varieties' fruits near or have higher than commercial varieties'. Therefore fresh consumption of these varieties can play an important role in healthcare nutrition.

Beside of apple consumption as fresh fruit this fruit species is important for the processing industry since it can be processed and sold in different ways by qualitative parameters.

According to expectations of food processing industry high refraction value of resistant varieties combined with high acid content. Furthermore, thanks to their favorable sugar/acid ratio these varieties have similar harmonic taste like 'Idared' and 'Watson Jonathan' commercial varieties having big importance in fresh consumption and food industrial processing.

'Rosmerta' resistant variety is good for changing 'Jonathan' varieties which have a determined role in Hungarian apple production during previous decades and grown for concentrate production today. Appearance and taste of 'Rosmerta' are very similar to 'Jonathan' however this variety has a great future in the Hungarian apple production due to its inner content value and its low costs to produce. 'Rosmerta' can be the determined variety of the concentrate industry. The fruits of 'Hesztia' and 'Cordelia' are recommended to enrich European and Hungarian assortments for fresh consumption. The new Hungarian apple varieties having different valuable characteristics (flesh firmness, polyphenol content) can be suitable for special food industrial purposes (puree, dried fruits) however it is necessary to test their adaptability.

\section{References}

Benzie, I. I. F., Strain, J. J. (1996): The Ferric Reducing Ability of Plasma (FRAP) as a measure of ,,antioxidant power”. The FRAP assay. Annal. Biochem., 239: 70-76.

Billy, L., Mehinagic, E., Royer, G., Renard, C., Arvisenet, G., Prost, C., Jourjon, F. (2008): Relationship between texture and pectin composition of two apple cultivars during storage. Postharvest Biology and Technology. 47 (3): 315-324.
Codex Alimentarius 3-1-558/93: Élelmiszerek vízoldható szárazanyag-tartalmának meghatározása.

Harker, F. R., Marsh, K. B., Young, H., Murray, S. H., Gunson, F. A., Walker, S. B. (2002): Sensory interpretation of instrumental measurements 2: sweet and acid taste of apple fruit. Postharvest Biol. Technol., 24: 241-250.

Khanizadeh, S., Tsao, R., Rekika, D., Yang, R., Charles, M. T., Rupasinghe, H. P. V. (2008): Polyphenol composition and total antioxidant capacity of selected apple genotypes for processing. Journal of Food Composition and Analysis, 21: 396-401.

KSH (2011): Agrár idősorok és cenzusok. Fontosabb gyümölcsfélék termésmennyisége, 1959-2009. http://portal.ksh.hu/pls/ksh/docs/ hun/agrar/html/tabl1_4_2_8.html

Kyriakidis, E. B., Psoma, E. (2001): Hydrocolloid interferences in the determination of pektin by the carbazole method. Journal of AOAC International, 84:1947-1949.

Lee, J.E., Chan,A.T. (2011): Fruit, vegetables and folate:cultivating the evidence for cancer prevention. Gastroenterology, 141 (1): 16-20.

Magyar Szabvány (1998): MSZ EN 12147:1998. Gyümölcs- és zöldséglevek. A titrálható savasság meghatározása.

Nara, K., Kato, Y., Motomura, Y. (2001): Involvement of terminalarabinose and -galactose pectic compounds in mealiness of apple fruit during storage. Postharvest Biol. Technol., 22: 141-150.

Nótin, B., Stéger-Máté, M., Juhász, R., Ficzek, G., Tóth, M., Barta, J. (2011): Effect of pre-treatment solutions of dried apple slices from several cultivars. Analecta Technica Szegedinensia, (1-2): 129-137.

Oliveira, M. C., Sichieri, R., Moura, A. (2003): Weight loss associated with a daily intake of three apples or three pears among overweight women. Nutr., 19: 253-256.

Petkovsek, M. M., Stampar, F., Veberic, R. (2007): Parameters of inner quality of the apple scab resistant and susceptible apple cultivars (Malus domestica Borkh.). Scientia Horticulturae, 114: 37-44.

Sanoner, P., Guyot, S., Marnet, N., Molle, D., Drilleau, J. F. (1999): Polyphenol profiles of French cider apple varieties (Malus domestica sp.). Journal of Agricultural and Food Chemistry, 47: 4847-4853.

Singleton, V. L., Rossi, J. A. (1965): Colometry of total phenolics with phosphomolybdic phosphotungstic acid ,reagents”. Am. J. Enol. Vitic., 16: 144-158.

Stégerné Máté, M. (2007): A gyümölcsfeldolgozás nyersanyagai. [In: Barta J. (szerk.): A gyümölcsfeldolgozás technológiái.] Mezögazda Kiadó, Budapest. 7-32. p.

Tóth, M. (2005): Six promising selections from the Hungarian apple breeding program for multiple resistance, Int. J. of Hort. Sci., 11 (3): 23-28.

Treutter, D. (2005): Significance of flavonoids in plant resistance and enhancement of their biosynthesis. Plant Biology., 7: 581-591.

Treutter, D., Feucht, W. (1990): The pattern of flavan-3-ols in relation to scab resistance of apple cultivars. J. Hortic. Sci., 65 : 511-517.

Usenik, V., Mikulic-Petkovsek, M., Solar, A., Stampar, F. (2004): Flavonols of leaves in relation to apple scab resistance. Z. Pflanzenkr. Pflanzenschutz, 111: 137-144.

Wolfe, K., Wu, X., Liu, R. H. (2003): Antioxidant activity of apple peels. Journal of Agricultural and Food Chemistry, 51: 609-614. 